the synergies among them-i.e., when our policies are mutually supportive and reinforcing.

This is not necessarily an easy task-it requires broad awareness of policies in place, and dialogue at the national policymaking and institutional levels. As we note at the end of the ACE-CIHE report, "ensuring that higher education around the world benefits from the best of what comprehensive, sustained, values-driven internationalization has to offer will take a great deal of creativity, substantial resources, and sheer hard work."

\section{Employment Opportunity as a Driver of Student Mobility}

\section{Christine Farrugia}

Christine Farrugia is senior research officer with the IIE Center for Academic Mobility Research and Impact at the Institute of International

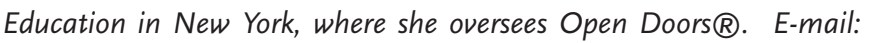
cfarrugia@iie.org.

$\mathrm{T}$ he opportunity to gain practical work experience is growing in importance as a driver of student mobility around the globe. For several years Open Doors $₫$ has documented the increasing numbers of US students who are engaging in work, internships, and volunteering abroad. In 20I3-20I4, there were more than 4I,000, including those who received academic credit for their work abroad and those who pursued non-credit work opportunities overseas. International students also value work experience to complement their studies, with more than I2 percent of the nearly I million international students in the United States in 20I4-20I5 engaging in Optional Practical Training (OPT), which is a period of work available for international students who have graduated from a US college or university. While recent extensions of the OPT eligibility period for graduates in STEM fields accounts for some of this proportion, students' willingness to stay on for work in growing numbers and for longer periods indicates how important this aspect of international education is for many students. Globally, we have seen that policies governing students' ability to work has impacted international student numbers in countries such as Canada, Germany, New Zealand, and the United Kingdom.

\section{WOrk is More Attractive for Some International STUDENTS}

Work opportunities are more influential drivers of mobility for students from certain countries than from others. While many students value the ability to gain practical work experience that will help them gain jobs back home or in their host country, others may be driven by economic conditions in their home countries that push them to take advantage of study-related work opportunities in the host country.

Many students from Asia pursue OPT in relatively high numbers, including those from India, Nepal, Taiwan, and China. Indian students are especially motivated by the opportunity to work in the host country following graduation. In the United States, Indian students are the leaders in OPT participation, with 22 percent of Indian students engaged in OPT in 20I4-20I5. At the same time, the number of Indian students in the United Kingdom has dipped over the past several years, following policy changes restricting the availability of post-study work visas following graduation. Following the implementation of the UK policy, Indian students fell by nearly 50 percent from $201 \mathrm{II}$ to $20 \mathrm{I} 4$, while their numbers increased by 70 percent in Australia, and 37 percent in the United States over the same time period.

While many students desire the opportunity to gain practical work experience along with their overseas studies, not all do so through work following graduation. The case of Brazilian students provides one example. While fewer than 5 percent of Brazilian students in the United States engaged in post-completion OPT in 20I4/20I5, over I2,000 were placed in internships alongside their studies in the United States in from 2011 through 20I5. These training opportunities have been incorporated into the Brazil government's Scientific Mobility Program as a key component of the students' academic and professional preparation so that they may return to Brazil with both academic knowledge and practical skills. Among students from some countries, work opportunities play a lesser role in their mobility patterns. For example, OPT accounts for just 2 percent of the international students from Saudi Arabia and Kuwait who were in the United States in 20I4-20I5. However, these low OPT rates may not be a function of low student interest in work opportunities, but may result from conditions of their governments' scholarship programs that encourage them to return their home countries once they graduate.

It is not just where the students come from that factors into their likelihood to pursue work opportunities related to their studies; who the students are matters as well. A special study (forthcoming) on US students' non-credit education abroad conducted by IIE as part of Generation Study Abroad found that slightly higher proportions of men engage in non-credit activities, including work, internships, and volunteering, than they do in traditional curriculum- 
based study abroad programs. Among students whose gender was reported by their institution, 40 percent were men, compared to 35 percent among study abroad students in traditional programs awarding academic credit, as documented in Open Doors. While men's participation in both forms of education abroad remain low, the slightly higher proportions engaging in non-credit education seem to align with anecdotal reports that male students are more apt to go abroad when they perceive a practical career benefit of their international experience.

\section{International students also value work experience to complement their studies, with more than 12 percent of the nearly 1 million international students in the United States in 2014-2015 engaging in Optional Practical Training (OPT).}

\section{The Value of INTERnational Co-CurRicular Work EXPERIENCE}

In the US domestic context, internships and work experience are widely recognized as important components of higher education programs and a vital way for students to gain work experience and practical skills that go beyond what they can learn in a classroom. Indeed, some academic programs require their students to complete internships as an integral part of their studies, as well as to prepare them for jobs following graduation. For international students, work experience in the United States provides similar educational benefits and provides them with critical skills in their field that will ultimately help them navigate a path to the working world in their host country, back home, or in a third country. When international students stay in the host country, they contribute their skills and knowledge to that country's development. In cases when international students ultimately work in another country, they help strengthen international cross-border ties in research and business.

Growing numbers of students are seeking out internships and work experience in countries outside of where they are pursuing their degree. Global internships are one way to make education abroad more meaningful for students by reflecting the reality of how students will use their international skills following graduation. While it is nice to study art in Florence, it might be better for a student's resume to work as part of a team building wells in Honduras, or to contribute to the development of a marketing strategy for a company in China. Such international experiences still provide the intercultural "soft" skills and transformative personal experiences that are familiar to many in the study abroad field, while also providing the opportunity for students to gain practical "hard" skills in a work context that can be easily translated to the job market down the line.

\section{The International Educa- tion Market: Some Emerging Trends}

\section{Neil Kemp}

Neil Kemp is deputy chair of the Council for Education in the Commonwealth and an international education consultant. He was formerly director of Education UK, British Council. E-mail: neil.kemp@nkeducation.com.

Tnternational student mobility has continued to surge, 1 as reflected in recent data from most major destination countries. Changes are occurring, some large and some subtle, and a selection of these trends is briefly discussed below. The major exception to strong enrollment growth in recruitment has been the United Kingdom, where tough immigration regulations have impacted directly on international student numbers.

\section{The China Question}

How many Chinese students will be studying internationally to years from now? The answer is very important, as numerous universities around the world have high dependency on recruiting Chinese students. The total number of Chinese studying internationally in $20 \mathrm{I} 2$ was estimated to be over 700,000 , three times more than the number of students from the second country, India. While the increasing capacity of Chinese universities might reduce outward mobility, demographic change will likely be a major factor, given that the number of young Chinese of higher education age is projected to decline significantly. However, currently international enrollment of Chinese students has continued to grow, to most leading destination countries: Australia up 8 percent, Germany 8 percent, and the United States II percent. Chinese student numbers in the United Kingdom were up about 5 percent in 2013 , with over half of the 17,300 new Chinese undergraduates came through some form of transfer arrangement-students commence in year 2 or 3 in the UK university after initial years in 